\title{
Lean Supply Chain Management (LSCM) Framework for Palm Oil Industry in Indonesia
}

\author{
Rangga Primadasa ${ }^{1}$, Salman Alfarisi ${ }^{2}$ \\ \{rangga.primadasa@umk.ac.id ${ }^{1}$, salman.alfarisi@umk.ac.id² \\ Departemen of Industrial Engineering Universitas Muria Kudus, Gondangmanis, Bae, PO Box 53 \\ Kudus, Jawa Tengah ${ }^{12}$
}

\begin{abstract}
Lean supply chain management (LSCM) is a research theme that is currently developing. This research objective is to offer LSCM frameworks of the palm oil industry in Indonesia. LSCM frameworks from Jasti and Kodali [6] were adopted, where seven of the eight pillars were chosen because they were in accordance with the palm oil industry. The seven pillars are including information technology management, supplier management, elimination of waste, customer relationship management, logistics management, top management commitment, continuous improvement. The simple additive weighting method (SAW) is used to measure and rank 39 LSCM frameworks subelements that are breakdown from 7 selected pillars. Three of the most important subelement is the long-term supplier partnership, seven waste throughout the supply chain, and value stream mapping.
\end{abstract}

Keywords: lean supply chain management, framework, palm oil industries in Indonesia.

\section{Introduction}

Today in global competition, physical displacement of goods has an important role in the efficiency and profitability of an industry. This moving goods system is expanding into supply chain management (SCM). Since it was first introduced by Oliver and Webber [1] the term "Supply chain" as a science developed rapidly . Masteika and Cepinskis [2] defines the supply chain as an overall activity of a raw material product supply to the customer, including supply of materials and parts, development and assembly, storage and monitoring of inventory, acceptance and management order, distribution through all channels, delivery to consumers and information systems needed to monitor all activities. Meanwhile supply chain management (SCM) is the activity of coordinating and integrating all of the above activities into an ongoing process.

Before SCM concept developed, there are developed in advance lean manufacturing concept. Lean manufacturing was first developed at Toyota Motor Company since 1960 [3], this system implemented several changes which initially put on the optimization of machines and work stations to impose on product flow through the whole process, applying production according to actual demand (rightsizing), improving self-monitoring capabilities of equipment to ensure quality (Jidoka), designing layout processes to facilitate sequences of operations, studying and increasing the speed of setups to enable rapid change and use of Kanban to coordinate the pull production form to connect one work stations with previous and after work ICCSET 2018, October 25-26, Kudus, Indonesia

Copyright (C) 2018 EAI

DOI 10.4108/eai.24-10-2018.2280624 
stations, and also connect companies with suppliers and allow JIT supply [4]. Lean manufacturing is a collective concept that begins by identifying value-added and non value added in the process, where non-value added is considered as a waste so it needs to be reduced. Bakas, Govaert and Langdeghem [5] states lean manufacturing focuses on shortening the timeline between customer order and shipping, as well as cutting costs and improving quality by identifying waste in the value stream.

The concept of lean manufacturing and supply chain management is integrated and led to a new concept of lean supply chain management (LSCM) . Vitasek et. al. [6] defines LSCM as a set of organizations that are directly linked by upstream and downstream flows of product, services, information and funds collaboratively working to reduce costs and waste by streamlining what is needed to meet consumer demands. LSCM Framework has grown widely in various types of industries, but no one has proposed for the palm oil industry, where Indonesia is the largest producer of crude palm oil (CPO) in the world.

According to data from the joint press release of Indonesian palm oil entrepreneurs [11], Indonesia's palm oil industry in 2016 reached 35.57 million tons with details of 32.52 million tons of CPO and 3.05 million tons of PKO. While in 2017 there was an $18 \%$ increase in palm oil production, where CPO production was 38.17 million tons and PKO was 3.05 million tons, bringing the total Indonesian palm oil production to 41.98 million tons.

Afonso and Chabita [7] proposed LSCM framework for SME and Jasti and Kodali [6] proposed LSCM Framewok for general industry, this paper is different beacause proposed LSCM Framework specific for palm oil industry. Jasti and Kodali [8] conducted a review of LSCM articles from 1988 to 2013, where from 748 articles he found 30 LSCM frameworks. After classifying and analyzing it, He propose a new framework with 8 main pillars. The purpose of this study is to establish LSCM frameworks for palm oil industry in Indonesia by making the 8 pillars of LSCM frameworks by Jasti and Kodali [8] as the basis of its foothold.

\section{Research methodology}

The study was conducted in six main stages: (1) describing the supply chain of palm oil industry in Indonesia, (2) describing the problems in the palm oil supply chain in Indonesia, (3) acquiring the eight pillars of lean supply chain management frameworks by Jasti and Kodali [8], (4) describes the suitability of the eight pillars of LSCM Frameworks by Jasti and Kodali [8] with the palm industry in Indonesia, (5) Breakdown of the eight pillars of LSCM frameworks by Jasti and Kodali [8] into sub-elements that can be applied to the palm oil industry in Indonesia. Finally (6) validate LSCM Frameworks pillars and sub-elements arranged using the SAW method. 


\subsection{Figure out palm oil industries supply chain in Indonesia}

Palm oil industries supply chain in Indonesia can be seen in Figure 1.

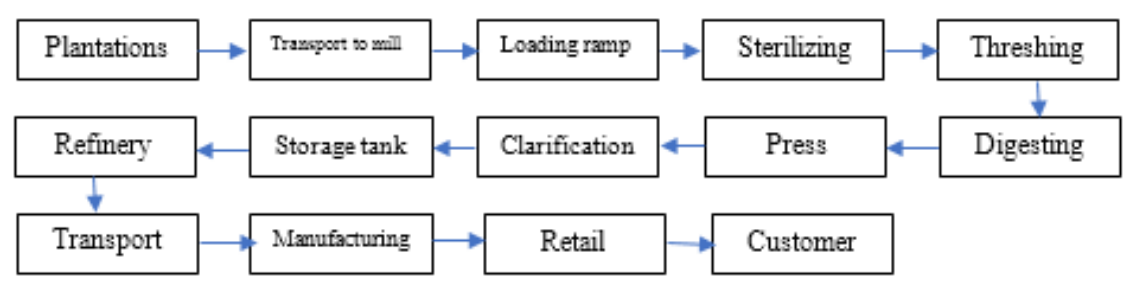

Fig 1. Supply Chain of Palm Oil Industry in Indonesia.

Palm oil plantations in Indonesia consist of three types, including nucleus estates (owned by the company), plasma estate, and private farmers' estate. All of the plantations have scheduled to harvest their FFB (fresh fruit bunches).Transportation department of palm oil company then scheduling the number of truck that will transport TBS from the plantations. FFB brought from the plantations was received at the weighbridge and then loaded in the loading ramp. From loading ramp TBS is inserted into the sterilizer station, here TBS is boiled using steam produced by a boiler integrated in the mill. The boiled FFB is then move in a threshing station to separate the palm fruit with the bunch. The empty bunches are then partially crushed as mixed in composting, while for palm fruit move to digesting station, where the boiled palm fruit is chopped and stirred while given steam, after stirring it is pressed to separate the cake from the nut. Nut then to the kernel station. While the portion of the fiber is headed to the boiler as fuel, and the crude oil goes to the clarification station. Crude oil is separated by mixed water and the dirt mixed in the clarification station, from this station CPO is then distributed to storage tanks for storage. CPO in the storage tank is then transported by ship to the refinery company. In general, the refinery process consists of physical refining and chemical refining processes. From palm oil refinery companies are sent to manufacturing companies as the raw material or complementary raw materials such as soap factories, cooking oil factories, food, biofuels, cosmetics. The resulting derivative products of palm oil are then circulated through retailers to reach consumers.

\subsection{Figure out problems on the supply chain of palm oil industry in Indonesia}

Palm oil industry has long supply chain from plantations until it becomes a final product such as cooking oil, soap, cosmetics, biofuels. There are several companies that own their own plantations, own mill, own refinery, and manufactured companies that use CPO as their own raw materials, for companies with upstream to downstream entities rather easier to manage their supply chain but for some companies that has different ownership of each entity from upstream to downstream is much more difficult to manage its supply chain. It is common for palm oil mill to stop because the storage tank is full, there is no buyer of CPO or late shipment schedule.

In plantations, after harvesting some berondolan left behind and not transported to the mill, it is losses. Fertilization waste due to poor fertilization process also often occurs. The efficiency FFB transportation to the mill somehow is less considered. The process on the mill itself is often not achieved because the FFB harvest from the plantaions is partially unripe and a lot of waste 
is included in the FFB transported. The use of water in the mill is often poorly controlled. The amount of oil losses in the mill is often high due to poor boiling or inefficient press due to unfit machinery. For CPO that is stored too long in the storage tank, the quality can be decreased where the FFA increases, this will make the price decrease due to increase processing costs in the refinery.

\subsection{Acquaired eight pillar LSCM Framework from Jasti and Kodali [8]}

Eight pillars of lean supply chain management (LSCM) of Jasti and Kodali [8] in this study acquired for palm oil industry but not for sub-element, because it will be evaluated first on suitability with palm oil Industry. These eight pillars including information and technology management, supplier management, elimination of waste, JIT Production, customer relationship management, logistics management, continous improvement.

\subsection{Describe the suitability eight pillars of LSCM by Jasti and Kodali [8] with palm oil industry in Indonesia}

Table 1. Explanation pillar of LSCM for palm oil industry.

\begin{tabular}{|c|c|c|}
\hline No & Pillars & Explanation \\
\hline 1 & $\begin{array}{l}\text { Information Technology } \\
\text { Management }\end{array}$ & $\begin{array}{l}\text { Information on plantations conditions, FFB harvest data, fertilizer use, } \\
\text { production data can be centralized using IT Management }\end{array}$ \\
\hline 2 & Supplier Management & $\begin{array}{l}\text { The arrangement of transporting FFB from the plantations, sending } \\
\text { machinery equipment for the mill can use supplier management. }\end{array}$ \\
\hline 3 & Elimination of Waste & $\begin{array}{l}\text { Waste from waiting time in the press station due to waiting too long } \\
\text { because setups in sterilizer station is not suitable, waste due to } \\
\text { overproduction of CPO while there is no purchase contract from } \\
\text { buyer, waste because the delivery of FFB not transported all due to the } \\
\text { lack of truck. All waste can be eliminated with pillar elimination of } \\
\text { waste. }\end{array}$ \\
\hline 4 & JIT Production & $\begin{array}{l}\text { The JIT principle is less applicable to process industries such as the } \\
\text { palm oil industry. So this pillar removed in LSCM frameworks for } \\
\text { palm oil industry. }\end{array}$ \\
\hline 5 & $\begin{array}{l}\text { Customer Relationship } \\
\text { Management }\end{array}$ & $\begin{array}{l}\text { Continuous evaluation of customer feedback, post sales service is an } \\
\text { example of an application of CRM that can be applied to any supply } \\
\text { chain in the palm oil industry. }\end{array}$ \\
\hline 6 & Logistics Management & $\begin{array}{l}\text { Material handling can be assigned to the mill, effective logistics } \\
\text { network design can be applied in sending FFB to the mill, sending } \\
\text { CPO to refineries. }\end{array}$ \\
\hline 7 & $\begin{array}{l}\text { Top Management } \\
\text { Commitment }\end{array}$ & $\begin{array}{l}\text { Employee empowerment in supply chain can be applied, leadership } \\
\text { development can also be used. at all levels of leadership in each level. }\end{array}$ \\
\hline 8 & Continuous Improvement & $\begin{array}{l}\text { Value stream mapping can be used and identifies all activities that are } \\
\text { valuable or not valuable in the supply chain. }\end{array}$ \\
\hline
\end{tabular}

Lean supply chain management (LSCM) pillars that are compatible with the palm oil industry are information technology management, supplier management, elimination of waste, customer relationship management, logistics management, top management commitment, top management commitment, continuous improvement. 


\subsection{Breakdown LSCM pillars to some sub-element for palm oil industry in Indonesia}

Table 2. Sub Elements 7 Plilar LSCM Frameworks of Palm Oil Industry.

\begin{tabular}{|c|c|c|}
\hline No & Pillars & Sub-element \\
\hline \multirow[t]{5}{*}{1} & Information & Enterprise resource planning system $(\mathrm{S} 1)$ \\
\hline & Technology & Modeling analysis and simulation tools (S2) \\
\hline & Management & Centralized database for documentation (S3) \\
\hline & & $\begin{array}{l}\text { Effective and information flow throughout supply chain transparency } \\
\text { (S4) }\end{array}$ \\
\hline & & Computer-aided decision-making supporting systems (S5) \\
\hline \multirow[t]{8}{*}{2} & Supplier & Strategic supplier development (S6) \\
\hline & Management & Supplier evaluation and development (S7) \\
\hline & & Long-term partnership supplier (S8) \\
\hline & & Supplier involvement in design (S9) \\
\hline & & Supplier feedback (S10) \\
\hline & & Supplier proximity (S11) \\
\hline & & Cost-based negotiation with suppliers (S12) \\
\hline & & Joint decision towards cost savings (S13) \\
\hline \multirow[t]{4}{*}{3} & Elimination of & Standard product and process (S14) \\
\hline & Waste & $5 \mathrm{~S}(\mathrm{~S} 15)$ \\
\hline & & Seven waste throughout the supply chain (S16) \\
\hline & & Visual control (S17) \\
\hline \multirow[t]{3}{*}{4} & Customer & Specification of value in terms customer point view (S18) \\
\hline & Relationship & Post sales services to customers (S19) \\
\hline & Management & Continuous evaluation of customers feedback (S20) \\
\hline \multirow[t]{6}{*}{5} & Logistics & Effective logistics network design (S21) \\
\hline & Management & Consignment inventory / vendor manage inventory (S22) \\
\hline & & Use third party logistics for transportation systems (S23) \\
\hline & & Elimination of buffer stock (S24) \\
\hline & & Master the demand forecasting process (S25) \\
\hline & & A, B , C Material handling (S26) \\
\hline \multirow[t]{7}{*}{6} & Top Management & Employee training in LSCM (S27) \\
\hline & Commitment & Leadership development (S28) \\
\hline & & Stable and long-term employment (S29) \\
\hline & & Cross-enterprise collaborative relationship (S30) \\
\hline & & Joint planning process with supplier (S31) \\
\hline & & Holistic strategy for integrating system (S32) \\
\hline & & Organization structure and associated relationship (S33) \\
\hline \multirow[t]{6}{*}{7} & Continuous & Multi-skilled workforce (S34) \\
\hline & Improvement & Built in quality system (S35) \\
\hline & & Value stream mapping (S36) \\
\hline & & Statistical process control (S37) \\
\hline & & Quality improvement teams (S38) \\
\hline & & Cross functional teams within the organization (S39) \\
\hline
\end{tabular}

LSCM framework for palm oil industry in Indonesia at this stage is proposed with 7 pillars with 39 sub-elements in it. 


\subsection{Validate using simple additive weighting method (SAW)}

The basic concept of SAW is find the sum of the weighted performance rates in all atributed [9]. At this stage, starting with 39 sub-elements of LSCM frameworks for palm oil industry will be given weight with the criteria of lean supply chain performance used by Arif-Uz-Zaman and Ahsan [10] adopting from SCOR model including cost (decreasing cost), time (repair of operating time), quality (product quality improvement), and flexibility ( increased flexibility) . All criteria is suitable to the context of palm oil industry since all of this is needed.

The second stage we give criteria percentage weight. The weight of the criteria in this study we make the same is 0.25 , with the assumption all criteria have same rate of importance. Next we assess each sub-element based on these four criteria. All score of subelement LSCM frameworks for palm oil industry in four criteria can be seen in table 3. Forth step is normalization of data, it was calculated as follows:

$$
\text { Enterprise resource planning system }(\mathrm{C} 1)=\frac{70}{\max \text { from } C 1 \text { column }}=\frac{70}{80}=0.875 \text {. }
$$

All are calculated like how we calculated above, the result can be seen in Table 3.The fifth stage is rank all sub-element by multiplying the weight of each criteria as follows:

Enterprise resource planning system $=(0.875)(0.25)+(1)(0.25)+(0.764)(0.25)$ $+(0.764)(0.25)=0.851$. After calculating the score is then sorted by the highest value. All score of sub element and the rank can be seen in Table 3 .

Table 3. Score, Results of Normalization and Ranking of LSCM Frameworks Sub-Elements for the Palm Industry in Indonesia

\begin{tabular}{|c|c|c|c|c|c|c|c|c|c|c|}
\hline \multirow{2}{*}{ Rank } & \multirow{2}{*}{$\begin{array}{c}\text { Sub- } \\
\text { element }\end{array}$} & \multicolumn{4}{|c|}{ Score } & \multicolumn{4}{|c|}{ Normalization } & \multirow{2}{*}{$\begin{array}{l}\text { Total } \\
\text { Score }\end{array}$} \\
\hline & & $\mathrm{C} 1$ & $\mathrm{C} 2$ & $\mathrm{C} 3$ & $\mathrm{C} 4$ & $\mathrm{C} 1$ & $\mathrm{C} 2$ & $\mathrm{C} 3$ & $\mathrm{C} 4$ & \\
\hline 1 & S8 & 80 & 85 & 70 & 90 & 1 & 1 & 0.823 & 1 & 0.955 \\
\hline 2 & S16 & 80 & 80 & 80 & 75 & 1 & 0.941 & 0.941 & 0.882 & 0.941 \\
\hline 3 & S36 & 80 & 75 & 80 & 80 & 1 & 0.882 & 0.941 & 0.941 & 0.941 \\
\hline 4 & S32 & 80 & 80 & 75 & 75 & 1 & 0.941 & 0.882 & 0.882 & 0.926 \\
\hline 5 & S14 & 80 & 70 & 85 & 75 & 1 & 0.823 & 1 & 0.882 & 0.926 \\
\hline 6 & S6 & 80 & 75 & 70 & 75 & 1 & 0.882 & 0.823 & 0.882 & 0.897 \\
\hline 7 & S34 & 70 & 75 & 75 & 80 & 0.875 & 0.882 & 0.882 & 0.941 & 0.895 \\
\hline 8 & S37 & 75 & 75 & 75 & 70 & 0.937 & 0.882 & 0.882 & 0.823 & 0.881 \\
\hline 9 & S21 & 75 & 75 & 70 & 75 & 0.937 & 0.882 & 0.823 & 0.882 & 0.881 \\
\hline 10 & S39 & 60 & 70 & 80 & 85 & 0.75 & 0.823 & 0.941 & 1 & 0.878 \\
\hline 11 & $\mathrm{~S} 3$ & 70 & 85 & 65 & 70 & 0.875 & 1 & 0.764 & 0.823 & 0.865 \\
\hline 12 & $\mathrm{~S} 24$ & 80 & 70 & 70 & 70 & 1 & 0.823 & 0.823 & 0.823 & 0.867 \\
\hline 13 & S27 & 70 & 70 & 75 & 75 & 0.875 & 0.823 & 0.882 & 0.882 & 0.865 \\
\hline 14 & S15 & 70 & 70 & 80 & 70 & 0.875 & 0.823 & 0.941 & 0.823 & 0.865 \\
\hline 15 & S38 & 65 & 70 & 75 & 80 & 0.812 & 0.823 & 0.882 & 0.941 & 0.864 \\
\hline 16 & S29 & 75 & 70 & 70 & 70 & 0.937 & 0.823 & 0.823 & 0.823 & 0.852 \\
\hline 17 & $\mathrm{~S} 1$ & 70 & 85 & 65 & 65 & 0.875 & 1 & 0.764 & 0.764 & 0.851 \\
\hline
\end{tabular}




\begin{tabular}{|c|c|c|c|c|c|c|c|c|c|c|}
\hline 18 & S23 & 65 & 75 & 65 & 80 & 0.812 & 0.882 & 0.764 & 0.941 & 0.850 \\
\hline 19 & S25 & 75 & 70 & 60 & 75 & 0.937 & 0.823 & 0.705 & 0.882 & 0.837 \\
\hline 20 & S31 & 70 & 75 & 65 & 70 & 0.875 & 0.882 & 0.764 & 0.823 & 0.836 \\
\hline 21 & S5 & 70 & 75 & 65 & 70 & 0.875 & 0.882 & 0.764 & 0.823 & 0.836 \\
\hline 22 & $\mathrm{~S} 30$ & 70 & 70 & 70 & 65 & 0.875 & 0.823 & 0.823 & 0.764 & 0.821 \\
\hline \multirow{2}{*}{ Rank } & \multirow{2}{*}{$\begin{array}{c}\text { Sub- } \\
\text { element }\end{array}$} & \multicolumn{4}{|c|}{ Score } & \multicolumn{4}{|c|}{ Normalization } & Total \\
\hline & & $\mathrm{C} 1$ & $\mathrm{C} 2$ & C3 & $\mathrm{C} 4$ & $\mathrm{C} 1$ & $\mathrm{C} 2$ & $\mathrm{C} 3$ & $\mathrm{C} 4$ & Score \\
\hline 23 & S9 & 65 & 70 & 70 & 65 & 0.812 & 0.823 & 0.823 & 0.823 & 0.820 \\
\hline 24 & S17 & 65 & 70 & 70 & 70 & 0.812 & 0.823 & 0.823 & 0.823 & 0.820 \\
\hline 25 & S13 & 80 & 60 & 65 & 65 & 1 & 0.705 & 0.764 & 0.764 & 0.808 \\
\hline 26 & $\mathrm{~S} 22$ & 70 & 75 & 60 & 65 & 0.875 & 0.882 & 0.705 & 0.764 & 0.806 \\
\hline 27 & S4 & 65 & 70 & 65 & 70 & 0.812 & 0.823 & 0.764 & 0.823 & 0.806 \\
\hline 28 & S19 & 65 & 65 & 65 & 75 & 0.812 & 0.764 & 0.764 & 0.882 & 0.806 \\
\hline 29 & $\mathrm{~S} 7$ & 65 & 70 & 65 & 70 & 0.812 & 0.823 & 0.764 & 0.823 & 0.806 \\
\hline 30 & $\mathrm{~S} 12$ & 80 & 60 & 65 & 60 & 1 & 0.705 & 0.764 & 0.705 & 0.794 \\
\hline 31 & S11 & 70 & 70 & 65 & 60 & 0.875 & 0.823 & 0.764 & 0.705 & 0.792 \\
\hline 32 & S10 & 65 & 65 & 65 & 70 & 0.812 & 0.764 & 0.764 & 0.823 & 0.791 \\
\hline 33 & S26 & 65 & 65 & 65 & 65 & 0.812 & 0.764 & 0.764 & 0.764 & 0.776 \\
\hline 34 & S35 & 60 & 65 & 70 & 65 & 0.75 & 0.764 & 0.823 & 0.764 & 0.775 \\
\hline 35 & S28 & 60 & 65 & 65 & 70 & 0.75 & 0.764 & 0.764 & 0.823 & 0.775 \\
\hline 36 & $\mathrm{~S} 2$ & 60 & 65 & 65 & 65 & 0.75 & 0.764 & 0.764 & 0.764 & 0.761 \\
\hline 37 & S20 & 60 & 60 & 65 & 60 & 0.75 & 0.705 & 0.764 & 0.705 & 0.731 \\
\hline 38 & S18 & 60 & 65 & 60 & 60 & 0.75 & 0.764 & 0.705 & 0.705 & 0.731 \\
\hline 39 & S33 & 60 & 60 & 65 & 60 & 0.75 & 0.705 & 0.764 & 0.705 & 0.731 \\
\hline
\end{tabular}

Note: $\mathrm{C} 1=$ Criteria 1 ( cost ); $\mathrm{C} 2=$ Criteria 2 (time); $\mathrm{C} 3=$ Criteria 3 (quality); $\mathrm{C} 4=$ criteria 4 (flexibility).

\section{Discussion}

Palm oil industry in Indonesia has a long supply chain, where everything starts from plantations then transports to the mill, next it is processed in several work stations including loading ramp, threshing, digesting, press, and clarification. Then the CPO is stored in a storage tank before it is sent to refinery, after that, it is sent to manufacture companies such as soap, make-up, cooking oil, or biofuel companies . LSCM Frameworks for the palm oil industry in Indonesia consists of seven pillars, after eliminating one pillar of LSCM frameworks from Jasti and Kodali [6] namely JT Production. JIT Production like pull production principle and kanban are not suitable system used in processes industries like in palm oil industry. From the seven pillar LSCM frameworks for the palm oil industry in Indonesia, then it breakdown into 39 subelement as seen in Table 2. After passing the assessment and ranking using simple additive weighting (SAW) method we have the three highest sub-element including long-term supplier partnership (S8) with score 0.955; Seven waste throughout supply chain (S16) with score 
0.941; and value stream mapping (S36) with score 0.941 . While the three lowest sub-elements are continuous evaluation of customer feedback (S20), customer point view's value in terms of value (S18), and organization structure and associated relationship (S33) with the same score of 0.731 .

\section{Conclusion}

LSCM Frameworks for palm oil industry in Indonesia has seven pillars including information technology management, supplier management, elimination of waste, customer relationship management, logistics management, top management commitment, continuous improvement. From the seven pillars in breakdown produce 39 sub-element with the order of importance shown in Table 3, where three of the most important sub-element is tong-term supplier partnership, seven waste throughout the supply chain, and value stream mapping. While for the three lowest sub-elements are organization structure and associated relationship, specification of value in terms customer point view, and continuous evaluation of customers feedback.

\section{References}

[1] R. K. Oliver and M. D. Weber, "Supply-chain management: logistics catches up with strategy," Logist. Strateg. Issues, 1982.

[2] I. Masteika and J. Čepinskis, "Dynamic Capabilities in Supply Chain Management," Procedia - Soc. Behav. Sci., 2015.

[3] A. M. N. Rose, B. M. Deros, M. N. A. Rahman, and N. Nordin, "Lean manufacturing best practices in SMEs," Int. Conf. Ind. Eng. Oper. Manag., 2011.

[4] M. D. Diego Fernando and L. Rivera Cadavid, "Lean manufacturing measurement: the relationship between lean activities and lean metrics," Estud. Gerenciales, 2007.

[5] O. Bakås, T. Givaert, and H. Van Landeghem, "Challenges and Success Factors for Implementation of Lean Manufacturing in European Smes," Mitip 2011, 2011.

[6] K. Vitasek, K. B. Manrodt, and J. Abbott, "What makes a lean supply cain?," Supply Chain Manag. Rev., 2005.

[7] H. Afonso and M. D. R. Cabrita, "Developing a lean supply chain performance framework in a SME: A perspective based on the balanced scorecard," in Procedia Engineering, 2015.

[8] N. V. K. Jasti and R. Kodali, "A critical review of lean supply chain management frameworks: proposed framework," Prod. Plan. Control, 2015.

[9] P. C. Fishburn, "Letter to the Editor-Additive Utilities with Incomplete Product Sets: Application to Priorities and Assignments," Oper. Res., 1967.

[10] K. Arif-Uz-Zaman and N. Ahsan, "Lean supply chain performance measurement," Int. J. Product. Perform. Manag., 2014.

[11] https://gapki.id/news/4140/refleksi-industri-kelapa-sawit-2017-dan-prospek-2018, accessed July 17,2018 . 